\title{
EFEKTIVITAS GERAKAN LITERASI SEKOLAH TERHADAP MINAT BACA DAN HASIL BELAJAR DI KELAS V SEKOLAH DASAR GUGUS II TEJAKULA TAHUN PELAJARAN 2019/2020
}

\author{
G. Kamardana ${ }^{1}$, I.W. Lasmawan ${ }^{2}$, N.K. Suarni ${ }^{3}$ \\ ${ }^{123}$ Program Studi Pendidikan Dasar \\ Universitas Pendidikan Ganesha \\ Singaraja, Indonesia \\ e-mail: gede.kamardana@undiksha.ac.id ${ }^{1}$, wayan.lasmawan@undiksha.ac.id ${ }^{2}$, \\ ketut.suarni@undiksha.ac.id ${ }^{3}$
}

\begin{abstract}
Abstrak
Penelitian ini bertujuan untuk mengetahui efektivitas gerakan literasi sekolah terhadap minat baca dan hasil belajar di kelas V SD Gugus II Tejakula Tahun Pelajaran 2019/2020. Populasi dalam penelitian 186 orang siswa. Sampel sebanyak 52 orang siswa diperoleh dengan teknik random sampling. Data minat baca dikumpulkan dengan kuesioner dan data hasil belajar dikumpulkan dengan tes objektif. Analisis data menggunakan analisis Manova. Berdasarkan analisisi data penelitian didapatkan hasil bahwa: 1) terdapat efektivitas Gerakan Literasi Sekolah (GLS) terhadap minat baca siswa pada Tema Panas dan Perpindahannya dan Tema Peristiwa dalam Kehidupan kelas V di SD Gugus II Tejakula Tahun Pelajaran 2019/2020, 2) terdapat efektivitas Gerakan Literasi Sekolah (GLS) terhadap hasil belajar siswa pada Tema Panas dan Perpindahannya dan Tema Peristiwa dalam Kehidupan kelas V di SD Gugus II Tejakula Tahun Pelajaran 2019/2020, 3) secara simultan, terdapat efektifitas secara simultan Gerakan Literasi Sekolah (GLS) terhadap minat baca dan hasil belajar siswa pada Tema Panas dan Perpindahannya dan Tema Peristiwa dalam Kehidupan kelas V di SD Gugus II Tejakula Tahun Pelajaran 2019/2020.
\end{abstract}

Kata Kunci: Gerakan Literasi Sekolah; Hasil Belajar; Minat Baca

\begin{abstract}
This study aims to determine the effectiveness of the school literacy movement towards reading interest and learning outcomes in the fifth grade of Tejakula II Elementary School in 2019/2020 Academic Year. The population in the study was 186 students. A sample of 52 students was obtained by random sampling technique. Data on reading interest was collected by questionnaire and data on learning outcomes were collected by objective tests. Data analysis using Manova analysis. Based on the analysis of research data, the results show that: 1) there is effectiveness of the School Literacy Movement (GLS) on students' interest in reading on Hot Themes and Displacement and Event Themes in Class V Life in Elementary School Cluster II Tejakula Academic Year 2019/2020, 2) there is effectiveness of Movement School Literacy (GLS) on student learning outcomes on Hot Themes and Displacement and Event Themes in Class V Life in Elementary School Cluster II Tejakula Academic Year 2019/2020, 3) simultaneously, there is a simultaneous effectiveness of School Literacy Movement (GLS) towards reading interest and student learning outcomes on Heat Themes and Their Displacement and Event Themes in Class V Life in Elementary School Cluster II Tejakula Academic Year 2019/2020.
\end{abstract}

Keywords: School Literacy Movements; Learning Outcomes; Interest In Reading

\section{PENDAHULUAN}

Pendidikan Nasional bertujuan untuk mengembangkan potensi peserta didik agar menjadi manusia yang beriman dan bertakwa kepada Tuhan Yang Maha Esa, beraklak mulia, sehat berilmu, cakap kreatif, mandiri dan bertanggung jawab serta menjadi warga negara yang demokratis dan bertanggung jawab. Untuk itu, pendidikan sebagai salah satu perwujudan kebudayaan manusia yang dinamis dan sarat dengan perkembangan sudah seharusnya sejalan dengan perubahan budaya kehidupan. 
Perubahan dalam pengertian perbaikan pada semua tingkatan perlu dilakukan terus menerus untuk antisipasi berbagai kepentingan di masa depan. Pendidikan yang mampu mendukung pembangunan masa mendatang adalah pendidikan yang mampu mengembangkan potensi anak didik, sehingga mereka mampu menghadapi dan memecahkan problema kehidupan yang dihadapinya. Pendidikan harus menyentuh potensi nurani maupun potensi kompetensi peserta didik. Konsepsi pendidikan tersebut terasa semakin penting ketika seseorang harus memasuki kehidupan di masyarakat dan dunia kerja, karena yang bersangkutan harus mampu menerapkan apa yang dipelajari di sekolah untuk menghadapi problema yang dihadapi dalam kehidupan sehari-hari saat ini maupun pada masa yang akan datang. Kunci kualitas pendidikan di sekolah adalah guru yang berkualitas dan metode belajar yang tepat, serta buku sebagai gerbang ilmu.

Salah satu pokok permasalahan yang ada di Indonesia saat ini yaitu terkait minat baca masyarakat yang rendah. Bahkan untuk di lingkungan pendidikanpun peserta didik di Indonesia memiliki tingkat minat baca yang rendah. Padahal, budaya membaca merupakan salah satu ciri peradaban modern. Hal ini diperkuat oleh hasil survei yang dilakukan oleh OECD (Organization for Economic Cooperation and Development) dalam bentuk PISA (Programme for International Student Assessment). Programme for International Student Assessment (PISA) sebagai program yang dilaksanakan oleh OECD (Organization for Economic Cooperation and Development) pada tahun 2018 yang melakukan penelitian untuk melihat kemampuan literasi membaca, matematika, dan sains siswa berumur 15 tahun di 78 negara. Negara Indonesia berada peringkat ke-72 dari 78 negara. Hasil peneletian tersebut skor rerata kemampuan baca negara-negara OECD adalah 487, sedangkan Indonesia memperoleh skor 371, Untuk Matematika dan IPA skor rerata berada diangka 489, sedangkan Indonesia memperoleh skor 379 untuk matematika dan 396 untuk IPA
(Kompas.com, 2019) Berdasarkan data tersebut, menunjukkan Indonesia masih berada jauh di bawah dari negara-negara lainnya.

Kenyataan di lapangan menunjukkan bahwa masih sangat banyak minat baca dan hasil belajar siswa yang rendah, hal ini terjadi di SD Negeri Gugus II Tejakula. Sesuai hasil observasi kami dengan guru-guru, lingkungan SD ini sangat padat penduduk dan dekat dengan jalan raya yang situasinya cukup bising untuk belajar. Orang tua siswa tak begitu peduli kepada pendidikan, mereka mengirim anak-anak mereka ke sekolah dengan tujuan agar tidak merepotkan mereka di rumah dan menyerahkan pendidikan sepenuhnya kepada sekolah. Selain hal tersebut guru dalam proses pembelajaran hanya terpaku pada satu buku ajar, padahal di perpustakaan sekolah buku penunjang pembelajaran masih banyak. Guru seolah-olah membatasi niat siswa dalam belajar, sehingga terkesan pembelajaran terpusat pada guru.

Hasil wawancara yang dilakukan dengan guru-guru kelas V SD Gugus II Tejakula, terkait minat baca dan hasil belajar siswa. Minat baca yang dimiliki oleh siswa masih sangat rendah, hal tersebut dibuktikan dengan minimnya waktu yang digunakan oleh siswa untuk membaca dan banyak siswa yang tidak memahami materi karena kurangnya minat membaca mereka. Siswa lebih senang bermain disaat waktu istirahat atau di rumah. Dengan minimnya minat baca yang dimiliki oleh siswa, maka berdampak pada rendahnya hasil belajar mereka. Hal ini dapat dilihat dari nilai ratarata ulangan harian mereka yang mendapatkan nilai rata-rata sebesar 62,32. Tentunya nilai tersebut masih rendah dari nilai KKM yang diharapkan.

Berdasarkan permasalahan tersebut, maka diperlukan upaya untuk meningkatkan kualitas pembelajaran di sekolah dasar, khususnya untuk meningkatkan minat membaca dan hasil belajar siswa. Salah satu upaya yang dapat dilakukan untuk meningkatkan minat baca dan hasil belajar siswa yaitu menggalakkan kembali gebrakan pemerintah yaitu Gerakan Literasi Sekolah 
(GLS). Gerakan Literasi Sekolah merupakan sebuah upaya yang dilakukan secara menyeluruh untuk menjadikan sekolah sebagai organisasi pembelajaran yang warganya literat sepanjang hayat melalui pelibatan publik (Kemendikbud, 2016).

Program literasi mendorong siswa untuk senantiasa haus akan ilmu pengetahuan, menjadikan mereka senang membaca dan akhirnya siswa memiliki wawasan yang lebih luas dan mendapatkan informasi baru. Literasi tidak lagi hanya dipahami sebagai transformasi individu semata, tetapi juga sebagai transformasi sosial. Rendahnya tingkat literasi sangat berkorelasi dengan kemiskinan, baik dalam arti ekonomi maupun dalam arti yang lebih luas. Literasi memperkuat kemampuan individu, keluarga, dan masyarakat untuk mengakses kesehatan, pendidikan, serta ekonomi dan politik. Dalam konteks kekinian, literasi melingkupi ilmu pengetahuan dan teknologi, keuangan, budaya dan kewargaan, kekritisan pikiran, dan kepekaan terhadap lingkungan sekitar. Oleh karena itu, masyarakat Indonesia harus menguasai literasi yang dibutuhkan untuk dijadikan bekal mencapai dan menjalani kehidupan yang berkualitas, baik masa kini maupun masa yang akan datang.

Menumbuhkan literasi di sekolah tentu bukan pekerjaan yang mudah. Tidak setiap sekolah memiliki lingkungan yang nyaman dan menyenangkan, sebagian sekolah mungkin terletak pada tempat yang tak kondusif, berupa lingkungan sempit dengan gedung yang harus berbagi dengan sekolah lain, sehingga tak ada ruang untuk menyimpan rak-rak buku.

Berdasarkan pendapat tersebut untuk mengembangkan budaya literasi maka diperlukan penyediaan bahan bacaan dan peningkatan minat baca anak. Sebagai bagian penting dari penumbuhan budi pekerti, minat baca anak perlu dipupuk sejak usia dini mulai dari lingkungan keluarga. Minat baca yang tinggi, didukung dengan ketersediaan bahan bacaan yang bermutu dan terjangkau, akan mendorong pembiasaan membaca dan menulis, baik di sekolah maupun di masyarakat. Dengan kemampuan membaca ini pula literasi dasar berikutnya (numerasi, sains, digital, finansial, serta budaya dan kewargaan) dapat ditumbuhkembangkan.

Sebagai bangsa yang besar, Indonesia harus mampu mengembangkan budaya literasi sebagai prasyarat kecakapan hidup abad ke-21 melalui pendidikan yang terintegrasi, mulai dari keluarga, sekolah, sampai dengan masyarakat. Pendidikan harus menyediakan kesempatan yang seluasluasnya bagi setiap peserta didik untuk memperoleh bekal pengetahuan, keterampilan dan nilai-nilai sebagai bekal untuk memasuki persaingan dunia yang semakin hari semakin ketat. Di samping kesempatan yang luas disediakan, namun yang penting juga adalah memberikan pendidikan yang bermakna (Meaningful learning). Karena hanya dengan

pendidikan yang bermakna peserta didik dapat dibekali keterampilan hidup (life skil) , sedangkan pendidikan tidak bermakna hanya akan menjadi beban hidup.

Kehidupan ke depan adalah sangat berat, penuh tantangan, dan kompetitif . Untuk itu diperlukan penataan kehidupan yang lebih baik dalam berbagai hal termasuk aspek pendidikan (Dantes, 2012). Hal tersebut di atas sejalan dengan apa yang UNESCO rekomendasikan, ada empat pilar pendidikan yaitu: 1) Belajar untuk berpengetahuan (To learn to Know); 2) Belajar untuk berbuat (To learn to Do); 3) Belajar untuk dapat hidup bersama (To learn to Live Together); dan 4) Belajar untuk jati diri (To learn to $\mathrm{Be}$ ). Para guru sebagai pengelola kegiatan pembelajaran perlu mencermati dan memahami dengan baik keempat pilar pendidikan tersebut, untuk digunakan sebagai landasan dalam merancang program, pembelajaran, merumuskan spesifikasi hasil belajar, memilih metode dan strategi pembelajaran, maupun dalam akumulasi kegiatan belajar mengajar di kelas

(Suastra, 2017). Untuk itu, guru-guru perlu mengembangkan metode inovatif dan kreatif untuk mengembangkan pembelajaran dengan strategi literasi. Hal ini dibutuhkan untuk mendampingi proses pemahaman siswa terhadap materi pembelajaran, mengembangkan kemampuan berpikir kritis mereka, juga 
untuk menjadikan proses pembelajaran menyenangkan.

Munculnya gerakan literasi sekolah merupakan sesuatu yang sangat diharapkan oleh banyak pihak jika melihat tingkat minat baca di Indonesia. Perannya yang penting dalam menumbuhkan budaya membaca tentu saja membuat gerakan literasi sekolah patut untuk diterapkan di setiap sekolah. Agar sekolah dapat menciptakan lingkungan sekolah dengan nuansa literasi tentu harus mengacu pada parameter yang telah dikemukakan oleh Beers, dkk tersebut. Tujuan gerakan literasi sekolah itu sendiri secara umum untuk menumbuhkembangkan budi pekerti melalui pembudayaan ekosistem literasi sekolah yang diwujudkan dalam gerakan literasi sekolah agar peserta didik menjadi pembelajar sepanjang hayat.

Pendukung jalannya gerakan literasi sekolah ada beberapa sarana yang diperlukan yaitu perpustakaan dan membuat Sudut Baca (Reading Corner). Dalam panduan GLS, Sudut Baca tidak hanya ada di dalam kelas, tetapi juga di area-area lain, sehingga bahan bacaan dapat diakses dengan mudah oleh siswa maupun guru. Memang ada sekolah yang sudah diperlengkapi dengan teknologi modern, akan tetapi masih banyak juga sekolah-sekolah yang mempunyai perpustakaan dengan kondisi yang tidak layak atau belum sama sekali tersedia sarana perpustakaan, sehingga hal ini menyebabkan tidak efektifnya pelaksanaan literasi. Selain itu, Sudut Baca di kelas juga terkendala mulai dari ruang kelas yang sempit, tidak tersedia bukubacaan yang memadai, hingga tidak adanya rak buku untuk memajang koleksi buku serta kurangnya pengawasan oleh guru sehingga siswa sering menaruh buku tidak pada tempatnya. Jika untuk membuat Sudut Baca di kelas saja susah, bagaimana mungkin sekolah akan mampu membuat area baca lain di seluruh sekolah?

Berdasarkan urian tersebut, Gerakan Literasi Sekolah (GLS) dapat dijadikan alternatif untuk meningkatkan minat baca dan hasil belajar siswa. Oleh karena itu adapun judul penelitian ini adalah "Efektivitas Gerakan Literasi Sekolah
(GLS) Terhadap Minat Baca dan Hasil Belajar Pada Tema Panas dan Perpindahannya dan Tema Peristiwa dalam Kehidupan Kelas V SD Gugus II Tejakula Tahun Pelajaran 2019/2020".

Tujuan dalam penelitian ini adalah; (1) untuk mengetahui efektivitas Gerakan Literasi Sekolah (GLS) terhadap minat baca siswa pada Tema Panas dan Perpindahannya dan Tema Peristiwa dalam Kehidupan di SD Gugus II Tejakula Tahun Pelajaran 2019/2020.; (2) untuk mengetahui efektivitas Gerakan Literasi Sekolah (GLS) terhadap hasil belajar siswa pada Tema Panas dan

Perpindahannya dan Tema Peristiwa dalam Kehidupan di SD Gugus II Tejakula Tahun Pelajaran 2019/2020; (3) ntuk mengetahui efektivitas secara simultan Gerakan Literasi Sekolah (GLS) terhadap minat baca dan hasil belajar siswa pada Tema Panas dan Perpindahannya dan Tema Peristiwa dalam Kehidupan di SD Gugus II Tejakula Tahun Pelajaran 2019/2020.

\section{METODE}

Jenis penelitian ini adalah penelitian ekperimen semu (quasi experiment). Disebut eksperimen semu karena belum memenuhi persyaratan rancangan penelitian eksperimen sesungguhnya (true experiment). Penelitian eksperimen semu tidak bisa memberikan kontrol perlakuan sepenuhnya atau tidak semua variabel dan kondisi eksperimen dapat diatur serta dikontrol secara ketat. Dalam penelitian eksperimen semu, random hanya dilakukan pada penentuan kelompok eksperimen dan kontrol. Pada penelitian ini kelompok eksperimen akan diberikan perlakuan berupa Gerakan Literasi Sekolah (GLS) dan pada kelompok kontrol tidak diberikan perlakuan khusus. Rancangan penelitian ini yaitu nonequivalent post-test only control group desain, yaitu hanya menggunakan posttest yang dilakukan pada akhir penelitian.

Populasi adalah keseluruhan obyek/subyek dalam penelitian yang mempunyai kualitas dan karateristik tertentu yang ditetapkan oleh peneliti untuk dipelajari dan kemudian ditarik kesimpulan. Populasi dalam penelitian ini adalah siswa kelas V Sekolah Dasar 
Gugus II Tejakula. Banyaknya populasi dalam penelitian ini adalah 186 siswa. sampel adalah sebagian populasi yang diambil untuk mewakili seluruh populasi. Bila populasi besar dan peneliti tidak mungkin mempelajari semua yang ada pada populasi, misalnya karena keterbatasan dana, tenaga dan waktu, maka peneliti dapat menggunakan sampel yang diambil dari populasi itu.

Sebelum dilakukan penentuan sampel penelitian, dilakukan uji kesetaraan pada semua sekolah yang ada Siswa Kelas V SD Gugus II Tejakula Kecamatan Tejakula Data yang digunakan dalam uji kesetaraan adalah nilai ulangan akhir semester (UAS) ganjil kelas V Sekolah Dasar. Secara keseluruhan untuk menguji kesetaraan nilai hasil ulangan akhir semester ganjil siswa kelas V Gugus

II Tejakula Kecamatan Tejakula menggunakan Anova. Uji kesetaraan yang dilakukan menggunakan bantuan SPSS 17.00 for Windows dengan signifikansi $5 \%$. Jika signifikansi $(\mathrm{sig})>0,05$, maka $\mathrm{HO}$ diterima.

Semua populasi dijadikan sampel untuk dijadikan kelas setara dilakukan uji kesetaraan. Sebelum diadakan pengambilan sampel, terlebih dahulu dilakukan pengujian kesetaraan kelas berdasarkan tes awal yang diberikan kepada siswa, untuk lebih meyakinkan kedua kelompok yang menjadi sampel tidak berbeda secara signifikan. Skor dari tes tersebut kemudian dianalisis dengan menggunakan uji Anava satu arah. Berdasarkan uji kesetaraan yang telah dilakukan dengan bantuan aplikasi SPSS 17.00 for Windows diketahui bahwa nilai $F$ $=0,367$ dan nilai signifikansi nilai siswa pada populasi tersebut adalah 0,162 lebih besar dari 0,05. Hal ini menunjukkan bahwa kemampuan siswa dari kedelapan sekolah siswa kelas V di SD Gugus II Kecamatan Tejakula, Kabupaten Buleleng dinyatakan dalam kondisi setara secara signifikan.

Setelah diketahui bahwa seluruh kelompok memiliki kemampuan setara, selanjutnya dilakukan pengundian untuk menentukan kelompok eksperimen dan kelompok kontrol. Pengundian sampel ini dilakukan pada semua kelas, karena setiap kelas mendapatkan kesempatan yang sama untuk dipilih menjadi sampel. Dua kelas yang muncul dalam undian langsung dijadikan kelas sampel. Dari hasil undian, diperoleh kelas $\mathrm{V}$ dari SD Negeri 1 Les, dan SD Negeri 2 Les. Kelas sampel yang telah didapatkan, kemudian diundi lagi untuk menentukan kelas eksperimen dan kelas kontrol.

Berdasarkan hasil undian yang telah diperoleh, yang menjadi kelas eksperimen dalam penelitian ini adalah siswa kelas $\mathrm{V}$ SD Negeri 1 Les, sedangkan kelas kontrol adalah siswa kelas V SD Negeri 2 Les. Banyaknya sampel dalam penelitian ini adalah 52 siswa.

Variabel dalam penelitian ini ada dua yaitu variabel bebas dan variabel terikat. Variabel bebas penelitian ini yaitu

Gerakan Literasi Sekolah (GLS), sedangkan variabel terikatnya yaitu minat baca dan hasil belajar. Penggunaan teknik dan alat pengumpulan data yang tepat memungkinkan diperolehnya data yang objektif. Penelitian ini dilakukan selama 8 kali pertemuan. Adapun data pada penelitian ini dikumpulkan dengan beberapa metode pengumpulan data yang disesuaikan dengan permasalahan yang dikaji pada penelitian ini. Sesuai dengan permasalahannya maka data yang diperlukan, yaitu minat baca dan hasil belajar. Dalam penelitian ini data minat baca diperoleh melalui pemberian kuesioner dan data hasil belajar melalui tes objektif tipe tes pilihan ganda.

Dalam penelitian ini menggunakan instrumen sesuai dengan jenis data dan sifat data yang akan dicari. Alat pengumpul data harus memenuhi persyaratan yaitu syarat validitas dan reliabilitas dalam mengungkap apa yang hendak diukur. Ada dua persyaratan yang hendak digunakan dalam pengumpulan data penelitian yaitu validitas dan reliabilitas. Validitas instrumen dalam penelitian ini meliputi dua segi yaitu validitas isi dan validitas butir. Validitas isi dibantu oleh dua orang ahli/ expert, kemudian dianalisis dengan teknik Gregory.

Sebelum instrumen digunakan, maka perlu diuji dahulu validitas dari masingmasing pertanyaan yang ada sebagai alat pengambilan data. Dengan demikian terlebih dahulu diadakan uji coba terhadap 
kuisioner kemudian hasil uji coba ini dianalisis. Kriteria yang digunakan dalam validitas adalah dengan membandingkan harga dengan tabel harga $r$ product moment pada taraf signifikansi $5 \%$. Tes dikatakan valid jika $r p b i>r$ pada taraf signifikansi $5 \%$. Tes yang divalidasi oleh para ahli dapat diketahui butir yang sesuai dan yang tidak sesuai. Begitu juga dapat diketahui upaya perbaikan untuk butir-butir tes yang sesuai. Pengujian terhadap reabilitas instrumen dilakukan melalui pendekatan ketetapan internal. Koyan (2011) reliabilitas alat ukur adalah keterandalan alat ukur atau keajegan alat ukur; artinya, kapanpun alat ukur itu digunakan akan menghasilkan hasil ukur yang relatif tetap. Untuk menentukan derajat reliabilitas tes, dapat digunakan kriteria yang dikemukakan oleh Guilford, 1951.

Teknik analisis deskriptif digunakan untuk mendeskripsikan data yang diperoleh. Data yang telah diperoleh dari penelitian dideskripsikan menurut masingmasing variabel, yaitu hasil belajar siswa dan minat baca sekolah dasar. Untuk melihat kecendrungan dari data hasil belajar dan minat baca siswa, dihitung rata-rata skor ideal dan standar deviasi ideal. Data yang telah diperoleh dari penelitian dideskripsikan menurut masingmasing variable. Oleh tujuannya seperti itu, maka akan dicari harga rerata (M), standar deviasi (SD), modus (Mo), dan median (Me) setiap variabel yang diteliti. Sebelum melakukan uji hipotesis maka harus dilakukan beberapa uji prasyarat analisis penelitian yaitu uji normalitas distribusi data, homogenitas varians, dan uji korelasi antar variabel. Uji prasyarat ini dilakukan untuk menjamin prasyarat

(asumsi) statistik yang dituntut terpenuhi. Uji prasyarat atau uji asumsi tersebut yaitu uji normalitas, uji homogenitas, dan uji korelasi antar variabel terikat.

Dalam Penelitian ini, diteliti pengaruh satu variabel bebas yaitu Gerakan Literasi Sekolah, terdapat dua variabel terikat yaitu hasil belajar dan minat baca siswa. Selain itu, dalam penelitian ini diajukan tiga hipotesis yang akan diuji. Untuk menguji hipotesis pertama dan kedua digunakan anava satu jalur (ANAVA A), untuk menguji hipotesis ketiga digunakan uji $F$ melalui analisis multivariate (MANOVA). Uji multivariate atau pengujian antar subjek yang dilakukan terhadap angkaangka signifikansi dari nilai $F$. angka signifikansi lebih kecil dari 0,05 berarti $\mathrm{H}_{0}$ ditolak yang artinya terdapat perbedaan signifikan terhadap minat baca dan hasil belajar siswa yang melaksanakan GLS dengan yang tidak melaksanakan GLS. Sebaliknya, jika angka signifikansi $F$ hitung lebih besar atau sama dengan 0,05 berarti $\mathrm{H}_{0}$ diterima, artinya tidak terdapat perbedaan signifikan terhadap minat baca dan hasil belajar siswa yang melaksanakan GLS dengan yang tidak melaksanakan GLS. Analisis MANOVA menggunakan bantuan program IBM SPSS Statistics 21 for windows. Semua pengujian hipotesis dilakukan pada taraf signifikansi $5 \%$.

\section{HASIL DAN PEMBAHASAN}

Data dalam penelitian ini dikelompokkan menjadi: 1) minat baca siswa yang melaksanakan GLS, 2) hasil belajar siswa yang melaksanakan GLS, 3) minat baca siswa yang tidak melaksanakan GLS, 4) hasil belajar siswa yang tidak melaksanakan GLS.

Selanjutnya dilakukan perhitungan sentral dari masing-masing data untuk mencari mean, median, modus, serta standar deviasi dari tiap-tiap kelompok data tersebut. Perhitungan tersebut dapat dilihat pada Tabel 1.

Tabel 1. Rekapitulasi Hasil Perhitungan Skor Minat Baca dan Hasil Belajar

\begin{tabular}{lllll}
\hline Variabel & $\mathrm{A}_{1} \mathrm{Y}_{1}$ & $\mathrm{~A}_{1} \mathrm{Y}_{2}$ & $\mathrm{~A}_{2} \mathrm{Y}_{1}$ & $\mathrm{~A}_{2} \mathrm{Y}_{2}$ \\
\hline $\mathrm{N}$ & 27 & 27 & 25 & 25 \\
Mean & 165,41 & 38,56 & 151,12 & 34,68 \\
Median & 165 & 38 & 151 & 34 \\
Modus & 163 & 34 & 153 & 34 \\
Standar Deviasi & 5,51 & 3,89 & 6,15 & 4,11 \\
\hline
\end{tabular}




\begin{tabular}{lllll}
\hline Variabel & $\mathrm{A}_{1} \mathrm{Y}_{1}$ & $\mathrm{~A}_{1} \mathrm{Y}_{2}$ & $\mathrm{~A}_{2} \mathrm{Y}_{1}$ & $\mathrm{~A}_{2} \mathrm{Y}_{2}$ \\
\hline Varians & 30,33 & 15,18 & 37,78 & 16,89 \\
Rentangan & 19 & 14 & 19 & 16 \\
Skor Minimum & 154 & 32 & 142 & 28 \\
Skor Maksimum & 173 & 46 & 161 & 44 \\
Jumlah & 4466 & 1041 & 3778 & 867 \\
\hline
\end{tabular}

Keterangan:

$\begin{array}{ll}\text { A1Y1 } & =\text { Minat baca siswa yang melaksanakan GLS } \\ \text { A1Y2 } & =\text { Hasil belajar siswa yang melaksanakan GLS } \\ \text { A2Y1 } & =\text { Minat baca siswa yang tidak melaksanakan GLS } \\ \text { A2Y2 } & =\text { Hasil belajar siswa yang tidak melaksanakan GLS }\end{array}$

\section{Efektivitas Gerakan Literasi Sekolah (GLS) Terhadap Minat Baca Siswa}

Hasil uji hipotesis pertama menunjukkan terdapat perbedaan minat baca antara kelompok siswa yang melaksanakan GLS dengan kelompok siswa yang tidak melaksanakan GLS. Hasil penelitian menunjukkan bahwa minat baca siswa yang melaksanakan GLS lebih baik dibandingkan dengan minat baca siswa yang tidak melaksanakan GLS pada Tema Panas dan Perpindahannya dan Tema Peristiwa dalam Kehidupan kelas $\mathrm{V}$ di SD Gugus II Tejakula Tahun Pelajaran 2019/2020. Hal ini ditunjukkan dengan rata-rata minat baca siswa yang melaksanakan GLS lebih tinggi daripada minat baca siswa yang tidak melaksanakan GLS.

Berdasarkan data hasil analisis multivariat dengan bantuan SPSS-17.00 for windows diperoleh nilai signifikansi lebih kecil dari 0,05, sehingga dapat ditarik simpulan bahwa terdapat perbedaan yang signifikan antara minat baca siswa yang melaksanakan GLS dengan minat baca siswa yang tidak melaksanakan GLS. Jadi dalam perbandingan antara yang melaksanakan GLS dengan yang tidak melaksanakan GLS, terdapat pengaruh perlakuan dalam pembelajaran terhadap minat baca siswa. Dengan kata lain, ada perbedaan antara yang melaksanakan GLS dengan yang tidak melaksanakan GLS.

Berdasarkan data hasil analisis tersebut, secara teoritis dapat dikatakan bahwa penggunaan GLS lebih baik dan efektif untuk meningkatkan minat baca siswa dalam proses pembelajaran. Minat membaca adalah tingkat kesenangan yang kuat dari seseorang dalam melakukan kegiatan membaca karena kegiatan tersebut menyenangkan dan memberi nilai positif kepadanya. Itu berarti sebagai sebuah aktivitas yang bernilai positif, membaca sebagai sebuah minat diberi perhatian yang serius melebihi aktivitasaktivitas lainnya.

Minat baca ditunjukkan oleh adanya keinginan yang kuat untuk melakukan kegiatan membaca. Orang yang memiliki minat baca yang tinggi senantiasa mengisi waktu-waktu luangnya dengan membaca. Orang yang demikian senantiasa haus akan bacaan. Berbeda halnya dengan orang yang memiliki minat baca yang rendah. Orang yang demikian biasanya enggan untuk melakukan kegiatan membaca. Keinginan untuk membaca rendah sekali, kegiatan membaca tidak menarik baginya. Melalui membaca siswa memperoleh pengetahuan dan wawasan baru yang semakin mencerdaskan kehidupannya sehingga mereka lebih mampu menjawab tantangan zaman di era globalisasi ini. Dalam pelaksanaannya, pengaruh dari gerakan literasi sekolah tidak serta merta langsung meningkatkan minat baca peserta didik tanpa adanya upaya yang keras dari semua pihak.

Gerakan Literasi Sekolah merupakan sebuah upaya yang dilakukan secara menyeluruh untuk menjadikan sekolah sebagai organisasi pembelajaran yang warganya literat sepanjang hayat melalui pelibatan publik. Dengan mengoptimalkan program Gerakan Literasi Sekolah maka siswa dibiasakan untuk membaca buku, hal ini dianggap dapat menumbuhkan minat baca serta meningkatkan keterampilan membaca agar pengetahuan 
dapat dikuasai secara lebih baik. Jika membiasakan diri untuk membaca sudah tertanam, tahap selanjutnya adalah terbentuk karakter gemar membaca, dan akhirnya memiliki budaya membaca yang baik.

Adanya Gerakan Literasi Sekolah dengan menghadirkan taman baca, pojok baca, perpustakaan dan jenis lainnya sangat membantu siswa untuk mengakses informasi. Gerakan Literasi Sekolah juga menekankan pada kegiatan literasi yang mencakup keterampilan berpikir menggunakan sumber - sumber pengetahuan dalam bentuk cetak, visual, digital, dan auditori. Dengan hadirnya halhal tersebut, jelas akan berdampak pada peningkatan minat baca oleh siswa.

Temuan dalam penelitian ini sejalan dengan hasil penelitian yang dilakukan oleh Wulanjani (2019) dengan penelitian yang berjudul "Meningkatkan Minat Membaca melalui Gerakan Literasi Membaca bagi Siswa Sekolah Dasar". Hasil penelitian menunjukkan bahwa melalui kegiatan-kegiatan yang menyenangkan sebagai upaya penerapan gerakan literasi membaca, para siswa menjadi lebih antusias dan termotivasi untuk lebih meningkatkan minat dalam membaca.

Berdasarkan hasil analisis dan temuan dalam penelitian lain yang sesuai dengan penelitian ini, jadi dapat disimpulkan bahwa terdapat perbedaan minat baca antara siswa yang melaksanakan GLS dengan siswa yang tidak melaksanakan GLS pada Tema Panas dan Perpindahannya dan Tema Peristiwa dalam Kehidupan siswa kelas $\mathrm{V}$ di SD Gugus II Tejakula Tahun Pelajaran 2019/2020.

\section{Efektivitas Gerakan Literasi Sekolah (GLS) Terhadap Hasil Belajar Siswa}

Hasil uji hipotesis kedua menunjukkan terdapat perbedaan hasil belajar antara siswa yang melaksanakan GLS dengan siswa yang tidak melaksanakan GLS. Hasil penelitian menunjukkan bahwa hasil belajar siswa yang melaksanakan GLS lebih baik dibandingkan dengan hasil belajar siswa yang tidak melaksanakan GLS pada Tema Panas dan Perpindahannya dan Tema
Peristiwa dalam Kehidupan siswa kelas V di SD Gugus II Tejakula Tahun Pelajaran 2019/2020. Hal ini ditunjukkan dengan rata-rata hasil belajar siswa yang melaksanakan GLS lebih tinggi daripada hasil belajar siswa yang tidak melaksanakan GLS.

Berdasarkan data hasil penelitian analisis multivariat dengan berbantuan SPSS-17.00 for windows diperoleh nilai signifikansi lebih kecil dari 0,05, sehingga dapat ditarik kesimpulan bahwa terdapat perbedaan yang signifikan antara hasil belajar siswa yang melaksanakan GLS dengan hasil belajar siswa yang tidak melaksanakan GLS. Jadi dalam perbandingan antara yang melaksanakan GLS dengan yang tidak melaksanakan GLS, terdapat pengaruh pendekatan pembelajaran terhadap hasil belajar siswa.

Melihat data hasil penelitian tersebut, secara teoritis dapat dikatakan bahwa hasil belajar siswa yang melaksanakan GLS lebih baik dan efektif. Kualitas pembelajaran merupakan cerminan dari kualitas pendidikan. Dalam meningkatkan kualitas pembelajaran khususnya hasil belajar, maka perubahan pola pikir ke arah yang lebih baik dan inovatif perlu terus diupayakan oleh para praktisi pendidikan. Sampai saat ini pembelajaran yang umum digunakan masih berorientasi pada pembelajaran yang berpusat pada guru (Teacher Centered) berupa latihan soal dan pembelajaran yang bersifat informatif. Pembelajaran yang berpusat pada guru (Teacher Centered) tersebut lebih berorientasi pada penyelesaian materi ajar sehingga bersifat teksbook dan tidak memperhatikan aspek pengetahuan awal siswa. Hal ini akan berdampak pada pemahaman siswa yang terbatas karena kegiatan belajar hanya terbatas pada kegiatan memorizing fact.

Gerakan Literasi Sekolah merupakan sebuah upaya yang dilakukan secara menyeluruh untuk menjadikan sekolah sebagai organisasi pembelajaran yang warganya literat yang dapat meningkatkan kemampuan mengakses, memahami, dan menggunakan sesuatu secara cerdas melalui berbagai aktivitas, antara lain membaca, melihat, menyimak, menulis, dan berbicara. Dalam pendidikan sekolah dasar tentu mengajarkan hal edukasi agar 
para siswanya memiliki ketrampilan yang mempuni. Dengan adanya peningkatan hal tersebut, jelas akan mempengaruhi hasil belajar siswa, yang berdampak pada peningkatan hasil belajar siswa.

Temuan dalam penelitian ini sejalan dengan hasil penelitian yang dilakukan oleh Yanti (2019) dengan penelitian yang berjudul "Pengaruh Aktivitas Literasi Terhadap Hasil Belajar Peserta Didik". Berdasarkan analisis data diperoleh simpulan bahwa ada pengaruh dan peningkatan dalam penerapan aktivitas literasi terhadap hasil belajar peserta didik kelas $\mathrm{V}$.

Berdasarkan hasil analisis dan temuan dalam penelitian lain yang sesuai dengan penelitian ini, jadi dapat disimpulkan bahwa terdapat perbedaan hasil belajar antara siswa yang melaksanakan GLS dengan siswa yang tidak melaksanakan GLS pada Tema Panas dan Perpindahannya dan Tema Peristiwa dalam Kehidupan siswa kelas V di SD Gugus II Tejakula Tahun Pelajaran 2019/2020.

\section{Efektivitas Secara Simultan Gerakan Literasi Sekolah (GLS) Terhadap Minat Baca Dan Hasil Belajar Siswa}

Hasil uji hipotesis ketiga menunjukkan terdapat perbedaan minat baca dan hasil belajar secara simultan antara siswa yang melaksanakan GLS dengan siswa yang tidak melaksanakan GLS. Hasil penelitian menunjukkan bahwa minat baca dan hasil belajar siswa yang melaksanakan GLS lebih baik dibandingkan dengan minat baca dan hasil belajar siswa yang tidak melaksanakan GLS pada Tema Panas dan Perpindahannya dan Tema Peristiwa dalam Kehidupan siswa kelas $\mathrm{V}$ di SD Gugus II Tejakula Tahun Pelajaran 2019/2020. Hal ini didasarkan pada hasil analisis MANOVA yang menunjukkan bahwa harga $\mathrm{F}$ hitung untuk Pillae Trace, Wilk Lambda, Hotelling's Trace, Roy's Largest Root dari implementasi GLS lebih kecil dari 0,05. Artinya semua nilai Pillae

Trace, Wilk Lambda, Hotelling's Trace, Roy's Largest Root signifikan. Dengan demikian, secara simultan Gerakan Literasi Sekolah (GLS) efektif terhadap minat baca dan hasil belajar siswa pada Tema Panas dan Perpindahannya dan Tema Peristiwa dalam Kehidupan di SD Gugus II Tejakula Tahun Pelajaran 2019/2020.

Berdasarkan data hasil analisis tersebut, secara teoritis dapat dikatakan bahwa pelaksanaan GLS lebih baik dan efektif untuk meningkatkan minat baca dan hasil belajar siswa dalam proses pembelajaran. Belajar dan mengajar merupakan dua konsep yang tidak bisa dipisahkan. Belajar menunjuk pada apa yang harus dilakukan seseorang sebagai subjek yang menerima pelajaran, sedangkan mengajar menunjuk pada apa yang harus dilakukan oleh guru sebagai pengajar. Dalam proses belajar-mengajar sering juga disebut dengan proses pembelajaran. Proses pembelajaran sangat dipengaruhi oleh minat siswa untuk belajar terutama minat baca siswa.

Minat baca ditunjukkan oleh adanya keinginan yang kuat untuk melakukan kegiatan membaca. Orang yang memiliki minat baca yang tinggi senantiasa mengisi waktu-waktu luangnya dengan membaca. Orang yang demikian senantiasa haus akan bacaan. Berbeda halnya dengan orang yang memiliki minat baca yang rendah. Orang yang demikian biasanya enggan untuk melakukan kegiatan membaca. Keinginan untuk membaca rendah sekali, kegiatan membaca tidak menarik baginya.

Selain minat baca pada proses pembelajaran ini menekankan pada apa yang menjadi tujuan yang ingin dicapai. Dalam hal ini menekankan pada hasil belajar. Hasil belajar merupakan tingkat penguasaan yang dicapai siswa dalam mengikuti program belajar mengajar sesuai dengan tujuan pendidikan yang ditetapkan meliputi aspek kognitif, afektif, dan psikomotor.

Untuk meningkatkan minat baca dan hasil belajar siswa, perlu di ciptakan kegiatan pembelajaran yang menarik sehingga merangsang siswa untuk belajar. Salah satu kegiatan yang dapat dilakukan yaitu dengan mengoptimalkan Gerakan Literasi Sekolah (GLS). Gerakan Literasi Sekolah merupakan sebuah upaya yang dilakukan secara menyeluruh untuk menjadikan sekolah sebagai organisasi 
pembelajaran yang warganya literat sepanjang hayat melalui pelibatan publik.

Atas uraian tersebut di atas, dapat dikatakan bahwa terdapat perbedaan minat baca dan hasil belajar secara simultan antara kelompok siswa yang melaksanakan GLS dengan kelompok siswa yang tidak melaksanakan GLS.

Temuan dalam penelitian ini sejalan dengan penelitian yang dilakukan oleh Batubara (2018) dengan penelitian yang berjudul "Implementasi Program Gerakan Literasi Sekolah Di Sekolah Dasar Negeri Gugus Sungai Miai Banjarmasin”. Hasil penelitian ini menunjukkan bahwa pelaksanaan program gerakan literasi sekolah di SDN Gugus Sungai Miai Banjarmasin berada pada tahap pembiasaan. Upaya-upaya yang dilakukan sekolah dalam melaksanakan program gerakan literasi sekolah adalah: (1) menambah buku pengayaan, (2) mendekatkan buku ke peserta didik dengan cara membuat area baca dan lingkungan yang kaya akan teks, (3) melaksanakan berbagai bentuk kegiatan literasi, dan (4) melibatkan publik dalam pelaksanaan gerakan literasi.

Berdasarkan hasil analisis dan temuan dalam penelitian lain yang sesuai dengan penelitian ini, jadi dapat disimpulkan bahwa secara simultan Gerakan Literasi Sekolah (GLS) efektif terhadap minat baca dan hasil belajar siswa pada Tema Panas dan

Perpindahannya dan Tema Peristiwa dalam Kehidupan di SD Gugus II Tejakula Tahun Pelajaran 2019/2020.

Telah terbukti secara empiris dalam penelitian ini, pertama, terdapat perbedaan minat baca antara siswa yang melaksanakan GLS dan siswa yang tidak melaksanakan GLS. Kedua, minat baca siswa yang melaksanakan GLS lebih tinggi daripada siswa yang tidak melaksanakan GLS. Ketiga, terdapat perbedaan hasil belajar antara siswa yang melaksanakan GLS dan siswa yang tidak melaksanakan GLS. Keempat, hasil belajar siswa yang melaksanakan GLS lebih tinggi daripada siswa yang tidak melaksanakan GLS. Dengan pengujian hipotesis yang ketiga terbukti bahwa terdapat perbedaan minat baca dan hasil belajar antara siswa yang melaksanakan GLS dengan siswa yang tidak melaksanakan GLS.

Dari uraian di atas dapat disimpulkan bahwa GLS yang diimplementasikan guru akan sangat mempengaruhi minat baca dan hasil belajar siswa, dan GLS dapat meningkatkan minat baca dan hasil belajar siswa.

\section{PENUTUP}

Berdasarkan hasil pengujian
hipotesis dan pembahasan hasil penelitian, maka dapat ditarik simpulan sebagai berikut.

a. Terdapat efektivitas Gerakan Literasi Sekolah (GLS) terhadap minat baca siswa pada Tema Panas dan Perpindahannya dan Tema Peristiwa dalam Kehidupan kelas V di SD Gugus II Tejakula Tahun Pelajaran 2019/2020.

b. Terdapat efektivitas Gerakan Literasi Sekolah (GLS) terhadap hasil belajar siswa pada Tema Panas dan

Perpindahannya dan Tema Peristiwa dalam Kehidupan kelas V di SD Gugus II Tejakula Tahun Pelajaran 2019/2020.

c. Terdapat efektifitas secara simultan Gerakan Literasi Sekolah (GLS) terhadap minat baca dan hasil belajar siswa pada Tema Panas dan

Perpindahannya dan Tema Peristiwa dalam Kehidupan kelas V di SD Gugus II Tejakula Tahun Pelajaran 2019/2020.

Berdasarkan temuan-temuan tersebut dapat disimpulkan bahwa terdapat efektivitas gerakan literasi sekolah (GLS) terhadap minat baca dan hasil belajar pada tema panas dan perpindahannya dan tema peristiwa dalam kehidupan kelas V SD Gugus II Tejakula Tahun Pelajaran 2019/2020.

Berdasarkan simpulan dan implikasi penelitian yang telah dipaparkan, maka dapat diajukan beberapa saran guna peningkatkan kualitas pembelajaran tematik sebagai berikut.

a. Kepada Guru

Hasil penelitian menunjukkan bahwa siswa yang melaksanakan GLS secara signifikan memiliki minat baca dan hasil belajar yang tinggi daripada siswa yang tidak melaksanakan GLS. Oleh karena itu, para guru disarankan melaksanakan GLS dalam pembelajaran di sekolah untuk 
meningkatkan minat baca dan hasil belajar.

b. Kepada Kepala Sekolah

Hendaknya kepala sekolah merancang atau memanajemen proses pembelajaran yang terjadi di sekolah melaksanakan GLS, agar dapat meningkatkan kualitas proses pembelajaran di sekolah tersebut.

c. Kepada Peneliti Lain

Mengingat keterbatasan waktu dan pokok bahasan yang digunakan dalam penelitian ini, maka disarankan kepada peneliti lain, agar melaksanakan penelitian sejenis dengan pemilihan materi yang berbeda dan waktu yang lebih lama untuk mendapatkan gambaran yang lebih meyakinkan mengenai GLS terhadap minat baca dan hasil belajar. Untuk penyempurnaan penelitian ini, disarankan kepada peneliti lain untuk mengadakan penelitian lanjut dengan melibatkan variabel-variabel lain, misalnya kemampuan membaca, kemampuan literasi siswa dan lain sebagainya.

\section{DAFTAR RUJUKAN}

Agung, A. A. G. 2014. Metodologi Penelitian Pendidikan. Jakarta:

Aditya Media Publishing.

Batubara, H.H. and Ariani, D.N., 2018. Implementasi Program Gerakan Literasi Sekolah di Sekolah Dasar Negeri Gugus Sungai Miai Banjarmasin. Jurnal Pendidikan Sekolah Dasar (JPsd), 4(1), pp.1529.

Candiasa, I Made. 2010. Statistik Multivariat Petunjk Analisis dengan SPSS. Program Pasca Sarjana Universitas Pendidikan Ganesha Singaraja.

Dantes, N. 2012. Analisis dan Desain Eksperimen. Singaraja: Program Pasca Sarjana Undiksha.

Kemendikbud. 2016. Jendela Pendidikan Dan Kebudayaan Gerakan Literasi Untuk Tumbuhkan Budaya Literasi.
Jakarta: Kementerian Pendidkan dan Kebudayaan.

Koyan. 2011. Asesmen dalam Pendidikan. Singaraja: Universitas Pendidikan Ganesha Press.

Pambudi, Dholina Inang. 2015. "Membangun Karakter Anak Melalui Keterampilan Literasi Dalam IPS". Repositori Universitas Ahmad Dahlan, I. pp. 1-3. ISSN 97860298647-4-8.

Wanelly, W., 2019. Implementasi Kebijakan Gerakan Literasi Sekolah (GLS) Dalam Rangka Menumbuhkan Minat Baca Siswa Di Sekolah Dasar. Jurnal Basicedu, 3(2), pp.406-413.

Wulanjani, Arum Nisma. Candradewi Wahyu anggraeni. 2019. Meningkatkan Minat Membaca melalui Gerakan Literasi Membaca bagi Siswa Sekolah Dasar.

Proceeding of Biology Education. Fakultas Keguruan dan IImu Pendidikan, Universitas Tidar (2019), 3 (1), 2631.

Yanti, Devi Ratna. Rochmiyati Rochmiyati. Loliyana Loliyana. 2019. Pengaruh Aktivitas Literasi Terhadap Hasil Belajar Peserta Didik. Jurnal Pedagogi. FKIP. Unila. Vol 2, No 3 Tahun 2019. 